РОЛЬ НЕПРИБУТКОВИХ ОРГАНІЗАЦІЙ УКРАЇНИ ДЛЯ ФІНАНСОВОЇ СИСТЕМИ ДЕРЖАВИ (НА ПРИКЛАДІ ГРОМАДСЬКИХ ОРГАНІЗАЦІЙ ТА КРЕДИТНИХ СПІЛОК)

\title{
THE ROLE OF UKRAINIAN NON-PROFIT ORGANIZATIONS FOR THE FINANCIAL SYSTEM OF THE STATE (EXAMPLE OF NGOS AND CREDIT UNIONS)
}

УДК [336.732:061.2](477)

DOI: https://doi.org/10.32843/bses.46-32

\section{Гладчук О.М.}

к.е.н., доцент,

доцент кафедри фрінансів і кредиту

Чернівецький національний університет

імені Юрія Федьковича

Ткачук І.Я.

к.е.н., доцент, докторант

Університет банківської справи

\section{Gladchuk Olga}

Yuriy Fedkovych Chernivtsi National

University

Tkachuk Iryna

Banking University

\begin{abstract}
y cmammi розглянуто діяльність таких неприбуткових організацій, як кредитні спілки та громадські організації. Визначено спільні та відмінні риси, характерні для їхньоі діяльності. Висвітлено вплив кредитних спілок та громадських організацій на кожну зі ссрер фрінансової системи держави. Визначено, що чей вплив кредитні спілки здійснюють більш цілеспрямовано, розширюючи фрінансові можливості конкретних економічних суб'єктів, а громадські організації забезпечують задоволення ширшого кола інтересів членів суспільства, підвищуючи рівень їхньої освіченості та благополуччя. Вказано на різну динаміку розвитку кредитних спілок (поступовий занепад) та громадських організацій (активний розвиток). Наголошено, що, зважаючи на роль в економічі, діяльність громадських організацій та кредитних спілок має велике значення для держави та населення, а враховуючи складну економічну ситуацію, вони мають широкі перспективи розвитку.

Ключові слова: неприбуткові організації, громадська організація, кредитна спілка, принципи взаємодопомоги та добровільності, фрінансова система держави.
\end{abstract}

В статье рассмотрена деятельность таких неприбыльных организаций, как кредитные союзы и общественные организации. Определены общие и отличительные черты, характерные для их деятельности. Освещено влияние кредитных союзов и общественных организаций на каждую из сфрер фринансовой системы государства. Определено, что такое влияние кредитные союзы осуществляют более целенаправленно, расииряя финансовые возможности конкретных экономических субъектов, а общественные организации обеспечивают удовлетворение широкого круга интересов членов общества, повышая уровень их образованности и благополучия. Указано на разную динамику развития кредитных союзов (постепенный упадок) и общественных организаций (активное развитие). Отмечено, что, учитывая роль в экономике, деятельность общественных организаций и кредитных союзов имеет большое значение для государства и населения, а учитывая сложную экономическую ситуацию, они имеют широкие перспективы развития.

Ключевые слова: некоммерческие организации, общественная организация, кредитный союз, принципы взаимопомощи и добровольности, фринансовая система государства.

The article highlights the peculiarities of the existing and activities of such non-profit organizations as credit unions and non-governmental organizations. The evolution of the legal basis for the functioning of credit unions (including their status) and non-governmental organizations is described. Common and distinctive features (characteristic of their activity) for the credit unions and non-governmental organizations are revealed. It is indicated that the main common feature of their activities is non-profitability (the basic principle of their operation). Satisfaction of economic and social interests of their members are important features too. Differences in the impact of credit unions and non-governmental organizations on the functioning of the subjects of economy are reflected in the more targeted and specific provision of financial services of credit unions in comparison with non-governmental organizations. At the same time, non-governmental organizations cover the wider range of interests of citizens. The influence of the activities of credit unions and public organizations on each sphere of the financial system of the state is covered. It is determined that credit unions exert a more deliberate influence, expanding the financial capacity of specific economic entities in comparison with NGOs, that provide a broader range of interests of members of society, increasing their level of education and financial well-being. It is noted that credit unions in Ukraine ignore the classical principles of credit cooperation, which also contributes to the deterioration of their development. The opposite dynamics in the development of national credit unions (gradual decline) and non-governmental organizations (active development) are pointed out. At the same time, it is emphasized that, due to the role in the economy, the activities of non-governmental organizations and credit unions in Ukraine are of great importance for the state and the population, and according to the difficult economic situation in Ukraine, these organizations have wide prospects for activity and development.

Key words: non-profit organizations, non-governmental organization, credit union, principles of activity.

Постановка проблеми. Функціонування суб'єктів економіки в Україні на сучасному етапі розвитку відбувається в умовах мінливого внутрішнього та зовнішнього середовища, надшвидкого нарощення обсягів інсрормації, цисрровізації та в умовах поглиблення глобалізаційних процесів. Відповідно, суттєво диверсисікувалася діяльність суб'єктів економіки, а 3-поміж них виділилася група так званих неприбуткових, неурядових організацій, діяльність яких зосереджена на забезпеченні потреб їх засновників/членів, а також на підвищення загального рівня соціального середовища. В Україні найбільш чисельними серед неурядових організацій є громадські організації та кредитні спілки. Однак за своєю сутністю вони, незважаючи на те що є об'єднаннями громадян, є різними, тому важливо дослідити особливості їх заснування та фрункціонування, а також їхню роль для елементів фінансової системи держави.

Аналіз останніх досліджень і публікацій. До дослідження питань діяльності та розвитку неурядових організацій в Україні зверталася низка дослідників, які створили основу для подальшого наукового дискурсу. Найбільш вагомий внесок у дослідження фрункціонування громадських організацій в Україні здійснили такі науковці, як О. Кири- 
ленко, Л. Василенко, С. Зелінський, В. Кодацький, Г. Шарлай. Так, О. Кириленко звернула увагу на необхідність удосконалення фрінансового механізму діяльності громадських фрормувань в умовах дефіциту централізованих фрінансових ресурсів та зауважила, що громадські організації та доброчинні фонди посідають важливе місце у фрінансовій системі держави [3]. Л. Василенко та С. Зелінський здійснили детальний теоретичний аналіз джерел фрінансування громадських організацій України відповідно до чинного на той момент (2002 р.) законодавства [1]. В. Кодацький та Г. Шарлай подали власне бачення теоретичних основ дослідження фрінансів громадських організацій, сформулювавши власне визначення фрінансів громадських організацій, а також поділивши фрінанси громадських організацій на дев'ять підланок [6]. Також за підтримки міжнародних організацій (ОБСЄ, Європейський центр некомерційного права, Український незалежний центр політичних досліджень) було здійснено низку фрундаментальних досліджень, присвячених фрінансуванню громадських організацій [2; 8; 14].

Різні аспекти утворення та фрункціонування кредитних спілок розглядали такі науковці, як Л.А. Савельєва, Н.Р. Швець, О.М. Осадець, В.В. Роєнко, А.С. Боженко та ін.

Л.А. Савельєва дослідила організаційно-правову фрорму кредитних спілок, підкресливши особливий статус цих фрінансових установ, а саме неприбуткову соціально-економічну природу, а також висвітлила основні аспекти господарської діяльності кредитної спілки [13]. Н.Р. Швець та О.М. Осадець здійснили дослідження кредитних спілок у структурі фрінансового посередництва: обґрунтували важливу роль кредитних спілок у структурі фрінансового посередництва, визначили пріоритетну модель організації фрінансових відносин на ринку з погляду ефективності діяльності кредитних спілок [15]. В.В. Роєнко, А.С. Боженко дослідили сучасний стан та проблеми функціонування кредитних спілок в Україні, наголосивши на тому, що «несприятливий вплив на динаміку показників здійснили світова орінансово-економічна криза та політична ситуація в Україні, що, своєю чергою, сприяло скороченню платоспроможності населення» [12].

Віддаючи належне внеску вищезазначених та інших науковців, зауважимо, що попередні дослідження діяльності неприбуткових організацій носили фррагментарний характер, адже досліджували окремі аспекти їх фрункціонування. Саме тому вважаємо за необхідне провести дослідження ролі неприбуткових організацій для фрінансової системи України на прикладі громадських організацій та кредитних спілок як найчисельніших і найвідоміших груп неприбуткових організацій.

Постановка завдання. Метою дослідження $€$ визначення ролі неприбуткових організацій у роз- витку фрінансової системи держави України на прикладі громадських організацій та кредитних спілок; порівняння спільних та відмінних ознак у фрункціонуванні цих неприбуткових організацій в Україні; визначення можливостей подальшого розвитку вітчизняних кредитних спілок та громадських організацій у сучасних реаліях.

Виклад основного матеріалу дослідження. Кредитні спілки, як і громадські організації, належать до неприбуткових організацій, проте вже на етапі створення вони суттєво відрізняються. Так, первинне право на об'єднання громадян у громадські організації забезпечує Конституція України [7, ст. 36], тоді як про кредитні спілки в ній не згадується.

Законодавче підґрунтя для фрункціонування кредитних спілок та громадських організацій забезпечують закони України «Про кредитні спілки» та «Про громадські об'єднання». Закон України «Про кредитні спілки» визначає кредитну спілку як неприбуткову організацію, засновану фрізичними особами, професійними спілками, їх об'єднаннями на кооперативних засадах із метою задоволення потреб ії членів у взаємному кредитуванні та наданні фрінансових послуг за рахунок об'єднаних грошових внесків членів кредитної спілки [10, ст. 1].

Закон України «Про громадські об'єднання» визначає громадську організацію як громадське об'єднання, засновниками та членами (учасниками) якого $є$ орізичні особи [9, ст. 1]. При цьому громадське об'єднання цим же ж Законом визначається як добровільне об'єднання фрізичних осіб та/або юридичних осіб приватного права для здійснення та захисту прав і свобод, задоволення суспільних, зокрема економічних, соціальних, культурних, екологічних, та інших інтересів [9, ст. 1].

При цьому слід зауважити, що відбулася еволюція правового статусу української кредитної спілки - від громадської організації до фрінансової установи фрінансового ринку, що діє на кооперативних засадах. Це відбулося 3 прийняттям Закону України «Про кредитні спілки» у 2001 р. Так, уперше Законом визначено кредитні спілки саме як фрінансові установи, винятковим видом діяльності яких $є$ надання фрінансових послуг.

Відмінними є й умови реєстрації громадських організацій та кредитних спілок. Створення кредитної спілки відбувається на підставі рішення установчих зборів. Проте кількість осіб, необхідних для заснування цих організацій, є відмінною. Так, для заснування громадської організації достатньо двох осіб старше 18 років, а для молодіжної та дитячої громадської організації - 14 років [9]. Водночас чисельність засновників (членів) кредитної спілки не може бути менше 50 осіб, які об'єднанні хоча б за однією з таких ознак: мають спільне місце роботи чи навчання або належать до однієї професійної спілки, об'єднання професійних спі- 
лок, іншої громадської чи релігійної організації або проживають в одному селі, селищі, місті, районі, області [10, ст. 6].

Порівняємо громадські організації та кредитні спілки й за іншими ознаками. Результати представимо в табл. 1.

Діяльність громадських організацій та кредитних спілок в Україні має багато спільних та відмінних рис. Головною спільною ознакою $\epsilon$ неприбутковий характер їхньої діяльності, а відмінною - більш спеціалізована діяльність кредитних спілок, концентрація саме на фрінансових послугах, тоді як діяльність громадських організацій характеризується широким спектром послуг.
Вплив фуункціонування громадських організацій та кредитних спілок на фрінансову систему наведемо через характеристику впливу на кожен з іії елементів.

На стан фрінансів населення (домогосподарств) кредитні спілки здійснюють безпосередній вплив, оскільки саме населення $€$ власниками/членами кредитних спілок та отримувачами їхніх спеціалізованих фрінансових послуг. Кредитні спілки розширюють фрінансові можливості діяльності населення (задовольняючи потреби своїх членів у взаємному кредитуванні та наданні фрінансових послуг за рахунок об'єднаних грошових внесків) та сприяють їхньому економічному розвитку.

Порівняння громадських організацій та кредитних спілок в Україні

Таблиця 1

\begin{tabular}{|c|c|c|}
\hline Ознака & Кредитні спілки & Громадські організації \\
\hline $\begin{array}{l}\text { Учасники/ } \\
\text { Члени/ } \\
\text { Засновники }\end{array}$ & $\begin{array}{l}\text { Певна монолітна спільнота осіб (трудові } \\
\text { колективи, профспілки, громадські, } \\
\text { релігійні організації, інші орган) }\end{array}$ & $\begin{array}{l}\text { Юридичні та фрізичні особи, резиденти та } \\
\text { нерезиденти, об'єднані за інтересами }\end{array}$ \\
\hline Мета діяльності & $\begin{array}{l}\text { Задоволення потреб членів у взаємному } \\
\text { кредитуванні та наданні фрінансових послуг } \\
\text { за рахунок об'єднаних грошових внесків } \\
\text { членів кредитної спілки }\end{array}$ & $\begin{array}{l}\text { Задоволення інтересів (суспільних політичних, } \\
\text { культурних тощо) та захист прав учасників та } \\
\text { інших осіб }\end{array}$ \\
\hline $\begin{array}{l}\text { Принципи } \\
\text { діяльності }\end{array}$ & $\begin{array}{l}\text { - добровільності вступу та свобода } \\
\text { виходу з кредитної спілки; } \\
\text { - рівноправності членів кредитної спілки; } \\
\text { - самоврядування; } \\
\text { - гласності }\end{array}$ & $\begin{array}{l}\text { - добровільності; } \\
\text { - самоврядності; } \\
\text { - вільного вибору території діяльності; } \\
\text { - рівності перед законом; } \\
\text { - відсутності майнового інтересу їхніх членів } \\
\text { (учасників); } \\
\text { - прозорості, відкритості та публічності }\end{array}$ \\
\hline $\begin{array}{l}\text { Джерела } \\
\text { коштів для } \\
\text { провадження } \\
\text { статутної } \\
\text { діяльності }\end{array}$ & \begin{tabular}{|l|} 
Вступні, обов'язкові, пайові та інші внески \\
членів кредитної спілки. Плата за надання \\
своїм членам кредитів та інших видів \\
послуг. Доходи від придбаних кредитною \\
спілкою державних цінних паперів. Грошові \\
та інші майнові пожертвування, благодійні \\
внески, гранти. Інші надходження, не \\
заборонені законодавством
\end{tabular} & $\begin{array}{l}\text { Державні кошти (державного бюджету, міських } \\
\text { бюджетів); кошти засновників та учасників; кошти } \\
\text { від благодійності (фрізичних осіб, юридичних } \\
\text { осіб, нерезидентів); від господарської діяльності } \\
\text { (власної; підприємств, установ, організацій, } \\
\text { заснованих та створених об'єднаннями } \\
\text { громадян); інші джерела }\end{array}$ \\
\hline $\begin{array}{l}\text { Організаційна } \\
\text { фрорма }\end{array}$ & $\begin{array}{l}\text { Фінансово-кредитна установа на } \\
\text { кооперативних засадах }\end{array}$ & Громадська організація \\
\hline Правовий статус & Неприбуткова організація & Неприбуткова організація \\
\hline $\begin{array}{l}\text { Державна } \\
\text { підтримка } \\
\text { (фрінансова та } \\
\text { організаційна) }\end{array}$ & $\begin{array}{l}\text { Визнання неприбутковою організацією, } \\
\text { сприятливе законодавче поле }\end{array}$ & $\begin{array}{l}\text { Державне фрінансування передбачене для } \\
\text { окремих видів ГО (інвалідів, молоді та спорту, } \\
\text { осіб, чорнобильців тощо). } \\
\text { Також щорічно фрінансується певний перелік гО } \\
\text { (зазвичай до 10) }\end{array}$ \\
\hline $\begin{array}{l}\text { Державний } \\
\text { нагляд }\end{array}$ & $\begin{array}{l}\text { Національна комісія,що здійснює державне } \\
\text { регулювання у сфері ринків фрінансових } \\
\text { послуг (буде НБУ) }\end{array}$ & Як такий відсутній \\
\hline $\begin{array}{l}\text { Операції, } \\
\text { послуги }\end{array}$ & $\begin{array}{l}\text { Фінансові послуги та послуги благодійного } \\
\text { характеру }\end{array}$ & Усі операції та послуги згідно із законодавством \\
\hline $\begin{array}{l}\text { Економічні цілі } \\
\text { діяльності }\end{array}$ & $\begin{array}{l}\text { Скорочення витрат членів спілки } \\
\text { на отримання фрінансових послуг, } \\
\text { використання надлишкового доходу для } \\
\text { стабільності спілки та нарахувань на паї } \\
\text { членів } \\
\end{array}$ & $\begin{array}{l}\text { Безпосередніх немає. } \\
\text { Економічні цілі діяльності можуть бути виділені } \\
\text { в статутах окремих організацій, проте вони } \\
\text { є опосередкованими (сприяння економічній } \\
\text { доброчесності, захист прав споживачів тощо) }\end{array}$ \\
\hline $\begin{array}{l}\text { Соціальні цілі } \\
\text { діяльності }\end{array}$ & $\begin{array}{l}\text { Самодопомога через взаємодопомогу, } \\
\text { активізація громадського життя, розвиток } \\
\text { освіти, просвіти у сорері економіки та } \\
\text { демократії }\end{array}$ & $\begin{array}{l}\text { Підвищення рівня освіченості населення, } \\
\text { захист прав та реалізація інтересів населення, } \\
\text { допомога потребуючим, розвиток громадянського } \\
\text { суспільства тощо }\end{array}$ \\
\hline
\end{tabular}

Джерело: складено авторами на підставі [9; 10] 
Населення $€$ першим й очевидним вигодонабувачем діяльності громадських організацій, адже саме 3 його представників вони фрормуються i саме на задоволення їхніх потреб прямо чи опосередковано (залежно від членства чи його відсутності) спрямована діяльність цих організацій. Діяльність громадських організацій спрямована на задоволення інтересів населення чи окремих його груп, захисту прав людини, підвищення рівня його освіченості та благополуччя.

На сореру фрінансів суб'єктів господарювання (фірм) кредитні спілки здійснюють опосередкований вплив, адже за поліпшення фрінансового стану населення кредитними спілками, населення як власники чи як клієнти фрірм мають можливість поліпшити фрінансовий стан, розширити фрінансову базу діяльності фрірм та стимулювати їх економічне зростання. 3 іншого боку, фрінанси неприбуткових організацій є складовою частиною сфери фрінансів суб'єктів господарювання, тому за економічного розвитку діяльності кредитних спілок відбуватиметься прямий вплив на розвиток цієї сорери фрінансової системи держави загалом.

Діяльність громадських організацій створює зовнішній ефект, підвищуючи загальну якість суспільного середовища. Цим пояснюється необхідність діяльності громадських організацій для суб'єктів господарювання: для підприємства насамперед важливим є вижити за умов жорсткої конкуренції та заробити при цьому прибуток, але подальший успіх буде залежати безпосередньо від умов того суспільного середовища, в якому компанія здійснює свою діяльність, адже якість соціального оточення $€$ не менш важливим чинником тривалого успіху, ніж економічні умови [5].

Ha сореру публічних (державних) фрінансів діяльність кредитних спілок реалізує опосередкований вплив, оскільки кредитні спілки, будучи платниками податків, є наповнювачами державного бюджету, і фрінансовий розвиток діяльності кредитних спілок збільшує обсяги відповідних надходжень і, таким чином, стимулює розвиток державних фрінансів.

Бюджетна фрорма відповідальності держави не відповідає тим потребам у суспільних благах, які могли б забезпечити належний рівень відтворення людського потенціалу [4, с. 43]. Неурядові ж організації на основі наближеності до споживачів своїх послуг здатні виявити реальні потреби всього населення та окремого індивіда того чи іншого регіону. Більше того, громадські організації, як і кредитні спілки, є платниками податків до бюджетів різних рівнів.

На таку сореру фрінансової системи, як фрінансовий ринок, діяльність кредитних спілок здійснює безпосередній вплив, адже кредитні спілки $€$ невід'ємним елементом сучасного фрінансового ринку. Сталий розвиток кредитних спілок зале- жить від стану фрінансового ринку держави, розширення та вдосконалення спеціалізованих фрінансових послуг, що надаються кредитними спілками, сприятиме розвитку фрінансового ринку. Варто відзначити, що влив на будь-яку з ланок фрінансової системи держави кредитними спілками $€$ двостороннім та прямим, оскільки позитивні зрушення у розвитку певної сфери фрінансової системи держави може дати поштовх і до розвитку в діяльності кредитних спілок. I навпаки, погіршення стану фрінансів певної сорери може призвести до спаду чи призупинення розвитку у функціонуванні кредитних спілок.

Громадські організації ж не чинять прямого впливу на стан та розвиток фрінансового ринку, втім, варто зауважити, що вони займаються просвітницькою діяльністю та сприяють розвитку громадянської освіти, у тому числі це стосується й фрінансової грамотності (такий вплив існує навіть тоді, коли серед цілей діяльності громадських організацій немає підвищення економічної та фрінансової грамотності, проте він є опосередкованим і проявляється в тому, що громадські організації зазвичай не володіють значними фрінансовими ресурсами, відповідно, не наймають високопрофесійних фрінансистів, тому керівники та учасники організацій змушені розбиратися хоча б в елементарних питаннях фрормування та розподілу бюджетів організацій).

Окрім того, варто відзначити і безпосередній вплив на розвиток економіки громадських організацій в економічно розвинених державах світу, який, утім, має великий потенціал до зростання і в Україні [11]:

- громадські організації створюють у середньому від 3\% до 9\% ВВП розвинених країн (наприклад, 5\% у Бельгії та 7,9\% у Канаді);

- у громадському секторі країн Європейського Союзу працевлаштовано від 4,4\% до 14\% працездатного населення або принаймні п'ять осіб із кожних ста;

- у громадському секторі країн Європейського Союзу працює у 10 разів більше людей, аніж у легкій промисловості, та у п'ять разів більше, ніж у харчовій промисловості;

- у країнах Центрально-Східної Європи громадські організації залучають утричі більше внутрішніх та зовнішніх інвестицій у соціальну сореру, ніж державні та комунальні установи соціального спрямування;

- внесок громадських організацій у ВВП країн Європейського Союзу зростає вдвічі швидше, ніж внесок легкої промисловості;

- громадянське суспільство у сукупності - це сьома економіка світу за ВВП (1,3 трлн умовних одиниць, що дорівнює ВВП Франції або Великої Британії);

- громадянське суспільство створило у світі понад 25 млн оплачуваних робочих місць (най- 
більша транснаціональна корпорація створює 3,5 млн робочих місць);

- 60\% представників громадянського суспільства (включно з волонтерами) зайняті у наданні послуг, із них 40\% зосереджено на соціальних, медичних та освітніх послугах.

Загалом вплив на економічне і соціальне життя економічних суб'єктів кредитною спілкою значне вужчий, аніж аналогічний вплив громадських організацій, однак цей вплив є більш цілеспрямованим.

Нині кредитні спілки не визнані неприбутковими організаціями у розумінні чинного Податкового кодексу України, оскільки винятковим видом їхньої діяльності $€$ надання фрінансових послуг, тому вони є платниками податку на прибуток.

Основні фрінансові показники діяльності кредитних спілок в Україні за останні десять років постійно зменшуються. Кількість самих кредитних спілок та їхніх активів зменшилася вдвічі, а кількість членів - у п'ять разів, що свідчить про різке зменшення довіри до кредитних спілок із боку їхніх членів та, як наслідок, вихід із них. Варто зазначити, що головною проблемою в діяльності кредитних спілок $€$ неповернення ними депозитів своїм членам. В Україні ще 32005 р. обговорюється питання створення Фонду гарантування вкладів кредитних спілок, однак зареєстровано два проєкти щодо можливого запровадження системи гарантування таких вкладів, але жоден із них не прийнято. Одним із варіантів виходу з кризи на ринку кредитних спілок є їх перетворення на кооперативні банки, однак, на нашу думку, активи цих орінансових інститутів є занадто малими, щоб утілити в життя цю ідею.

Необхідно зазначити, що в Україні ігноруються класичні засади кредитної кооперації, зокрема ставки за позичками є значно вищими, ніж у банках (а мало би бути навпаки), практично немає соціальної спрямованості в діяльності кредитних спілок - принципу фрінансової взаємодопомоги, а основним виступає принцип отримання додаткових доходів. Саме таке зміщення в акцентах фрункціонування сучасних українських кредитних спілок, а також універсалізація та розширення діяльності банківських установ і спричинили занепад у фрункціонуванні українських кредитних спілок, що робить подальші перспективи їхньої діяльності доволі складними і суперечливими, адже в такому вигляді кредитні спілки не зовсім потрібні фрінансовій системі держави, й лише максимальне повернення до класичних принципів кредитної кооперації дасть змогу відродити ці небанківські фрінансові інститути.

Висновки 3 проведеного дослідження. Спектр послуг, що надаються неурядовими організаціями, є дуже широким. Підтвердженням цього є діяльність кредитних спілок та громадських органі- зацій в Україні, які забезпечують реалізацію інтересів як своїх членів, так і членів усього суспільства. Діяльність кредитних спілок та громадських організацій має спільні риси: неприбутковість (базовий принцип їх фрункціонування), задоволення економічних та соціальних інтересів своїх членів. Відмінності впливу діяльності кредитних спілок і громадських організацій на фрункціонування економічних суб'єктів відображається більш цілеспрямованим та конкретизованим наданням фрінансових послуг кредитними спілками та широким колом інтересів громадських організацій.

Визначивши вплив функціонування громадських організацій та кредитних спілок на різні складники фрінансової системи, варто відзначити, що кредитні спілки здійснюють переважно безпосередній вплив, розширюючи фрінансові можливості діяльності конкретних економічних суб'єктів. Громадські організації своєю діяльністю також впливають на стан розвитку фрінансової системи, адже забезпечують, зокрема, задоволення інтересів членів суспільства, підвищення рівня їхньої освіченості та фрінансового благополуччя.

Динаміка розвитку діяльності кредитних спілок в Україні за останнє десятиліття свідчить про поступовий занепад, ураховуючи неприбутковий характер їхньої діяльності, було б дуже потрібне швидке й ефективне державне втручання в дану систему, щоб кредитні спілки просто не «відмерли» як раритет на ринку фрінансових послуг. Громадські організації, навпаки, розвиваються в Україні швидкими темпами й розширюють межі своїх інтересів, усе більше охоплюючи різноманітні сорери суспільного життя, зокрема й фрінансову. Проте, зважаючи на стрімкий розвиток громадянського суспільства в Україні та на роль, яку відіграють неприбуткові організації в економіці нашої держави, вважаємо, що як громадські організації, так і кредитні спілки мають широкий потенціал для розвитку.

\section{БІБЛІОГРАФІЧНИЙ СПИСОК:}

1. Василенко Л.І., Зелінський С.В. Фінансове забезпечення діяльності і розвитку громадських організацій. Фінанси України. 2002. № 8. С. 33-39.

2. Хадзі-Місєва К., Фабріція Сапліссон Огляд схем державного фрінансування організацій громадянського суспільства. Державне фрінансування організацій громадянського суспільства. Як запровадити європейські стандарти? Київ. 2010. С. 191-223.

3. Кириленко О. Особливості фрінансів громадських організацій і доброчинних фрондів. Фінанси України. 1998. № 1. С. 59-63.

4. Кириленко О.П. Міжнародний досвід застосування нетрадиційних методів фрінансування громадських організацій. Науковий огляд. 2015. № 10(20). C. 21-28.

5. Коваленко В.В., Юлдашев О.О. Громадські організації в Україні: взаємодія між трьома секторами. Київ : МАУП, 2007. 224 с. 
6. Кодацький В.П., Шарлай К.Г. Теоретичні основи фрінансів громадських організацій. Економічний вісник Донбасу. 2009. № 4. С. 130-132.

7. Конституція України : Закон України від 28 червня 1996 р. № 254к/96-ВР. Відомості Верховної Ради України. 1996. № 30. Ст. 141. URL : https://zakon.rada.gov.ua/laws/show/254\%D0\%BA/96\%D0\%B2\%D1\%80/print (дата звернення: 01.11.2019).

8. Національні та міжнародні механізми фрінансування громадянського суспільства. Міжнародні заходи зміцнення довіри між державою та громадянським суспільством. Київ : Фенікс, 2011. 336 с.

9. Про громадські об'єднання : Закон України від 22 червня 2012 р. № 5026-VI / Верховна Рада України. URL : https://zakon.rada.gov.ua/laws/show/4572-17/ print (дата звернення: 01.11.2019).

10.Про кредитні спілки : Закон України. Редакція від 1 січня 2016 р. № 2908-III. URL : https://zakon.rada.gov.ua/laws/show/2908-14 (дата звернення: 01.11.2019).

11. Про стан розвитку громадянського суспільства в Україні / Національний інститут стратегічних досліджень. 2012. URL : http://www.niss.gov.ua/public/ File/2012_nauk_an_rozrobku/stan_poz_gp_sus.pdf (дата звернення: 01.11.2019).

12. Роєнко В.В., Боженко А.С., Іванова А.С. Сучасний стан та проблеми функціонування кредитних спілок в Україні. Глобальні та національні проблеми економіки. 2016. Вип. 10. URL : http://global-national. in.ua/archive/10-2016/220.pdf (дата звернення: 01.11.2019).

13. Савельєва Л.А. Кредитні спілки як суб'єкт цивільно-правових відносин. Наукові записки. Т. 53. URL : http://ekmair.ukma.edu.ua/bitstream/handle/ 123456789/7144/Savelieva_Kredytni_spilky_yak subiekt_tsyvilno-pravovykh_vidnosyn.pdf?sequence=1 \&isAllowed=y (дата звернення: 01.11.2019).

14.Шатор Б. Міжнародні практики фрінансування організацій громадського суспільства. ОБСЄ, 2010. $162 \mathrm{c.}$.

15. Швець Н.Р., Осадець О.М. Кредитні спілки в структурі фрінансового посередництва. Науковий огляд. 2015. № 8. URL : http://oaji.net/ articles/2015/797-1445616411.pdf (дата звернення: 01.11.2019).

\section{REFERENCES:}

1. Vasylenko L. I., Zelinskyy S. V. (2002) Finansove zabezpechennia diialnosti i rozvytku hromadskykh orhanizatsii [Financial support of activity and development of public organizations]. Svit finansiv [The world of finance], no. 8, pp. 33-39.

2. Khadzi-Misieva K., Fabritsiia Saplisson (2010) Ohliad skhem derzhavnoho finansuvannia orhanizatsii hromadianskoho suspilstva European Center for Nonprofit Law Ohliad skhem derzhavnoho finansuvannia dlia hromadianskoho suspilstva [Overview of public funding schemes for civil society]. Kyiv. pp. 191-223. (in Ukrainian)

3. Kyrylenro O. (1998) Osoblyvosti finansiv hromadskykh orhanizatsii i dobrochynnykh fondiv [Features of finances of public organizations and charitable foundations]. Svit finansiv [The world of finance], no. 1, pp. 59-63.
4. Kyrylenro O. (2015) Mizhnarodnyi dosvid zastosuvannia netradytsiinykh metodiv finansuvannia hromadskykh orhanizatsii [International experience in applying non-traditional methods of financing of public organizations]. Naukovyi ohliad [Scientific review], no. 10 (20), pp. 21-28.

5. Kovalenko V., Juldashev O. (2007) Hromadski orhanizatsii $v$ Ukraini: vzaiemodiia mizh troma sektoramy [NGOs in Ukraine: interaction between three sectors]. Kyiv, MAUP. (in Ukrainian)

6. Kodatskyi V., Sharlai K. (2009) Teoretychni osnovy finansiv hromadskykh orhanizatsii [Theoretical Foundations of Finance of NGOs]. Ekonomichnyi visnyk Donbasu [Economic Bulletin of Donbass], no. 4, pp. 130-132.

7. Constitution of Ukraine. Information of the Verkhovna Rada of Ukraine № 30, art. 141. Available at: https://zakon.rada.gov.ua/laws/show/254\%D0\%BA/96\%D0\%B2\%D1\%80/print (accessed 1 November 2019).

8. Feniks (2012) Natsionalni ta mizhnarodni mekhanizmy finansuvannia hromadianskoho suspilstva. Mizhnarodni zakhody zmitsnennia doviry mizh derzhavoiu ta hromadianskym suspilstvom [National and international mechanisms for financing civil society. International confidence-building measures between the state and civil society] Kyiv: Feniks.

9. Zakon Ukrainy "Pro gromadski objednannia" 4572-VI Redaktsiia vid 22.07.2018 [Law of Ukraine "On public associations" № 4572-VI Version from 2018, July 7]. Available at: https://zakon.rada.gov.ua/laws/ show/4572-17] (accessed 1 November 2019).

10.Zakon Ukrainy "Pro kredytni spilky № 2908-III Redaktsiia vid 01.01.2016" [Law of Ukraine "On Credit Unions" № 2908-III Version from 2016, January 1]. Available at: https://zakon.rada.gov.ua/laws/show/2908-14 (accessed 1 November 2019).

11. National Institute for Strategic Studies (2012) Pro stan rozvytku hromadianskoho suspilstva v Ukraini. Dopovid [On the state of development of civil society in Ukraine. Report]. Available at: http://www.niss.gov.ua/ public/File/2012_nauk_an_rozrobku/stan_poz_gp_sus. pdf (accessed $1 \overline{\text { November }}$ 2019).

12. Roienko V. V., Bozhenko A. S., Ivanova A. S. (2016) Suchasnyi stan ta problemy funktsionuvannia kredytnykh spilok v Ukraini [Current state and problems of credit unions functioning in Ukraine]. Hlobalni ta natsionalni problemy ekonomiky [Global and national problems of economy], 10. Available at: http://global-national. in.ua/archive/10-2016/220.pdf (accessed 1 November 2019).

13. Saveleva L. A. (2006) Kredytni spilky yak subiekt tsyvilno-pravovykh vidnosyn [Credit unions as a subject of civil relations]. Naukovi zapysky [Scientific notes], Vol. 53. Available at: http://ekmair.ukma.edu.ua/handle/123456789/7144 (accessed 1 November 2019).

14. Shator B. (2010) Mizhnarodni praktyky finansuvannia orhanizatsii hromadskoho suspilstva [International Financing Practices for CSOs.] OSCE. (in Ukrainian)

15. Shvets N. R., Osadets O. M. (2015) Kredytni spilky v strukturi finansovogo poserednyctva [Credit unions in the structure of financial intermediation]. Naukovyi ohliad [Scientific review], no. 8, Available at: http://oaji.net/articles/2015/797-1445616411.pdf (accessed 1 November 2019). 